\title{
Aktualisasi Makna Kerjasama (Living Al-Qur'an-Hadist di Desa Koto Petai-Kerinci-Jambi)
}

(Actualization of the Cooperation Meaning (Living Al-Qur'an-Hadith in Koto Petai Village-Kerinci-Jambi))

\author{
Rasidin $^{1}$, Nurfadliyati ${ }^{2}$, Kusmana ${ }^{3}$ \\ ${ }^{12}$ UIN Sulthan Thaha Saifuddin Jambi, ${ }^{3}$ UIN Syarif Hidayatullah Jakarta \\ ${ }^{1}$ rasidin@uinjambi.ac.id, ${ }^{2}$ fadliyati2803@gmail.com, ${ }^{3}$ kusmana@uinjkt.ac.id
}

DOI: $10.29240 /$ alquds.v5i2.2535

Submitted: 2021-02-08 | Revised: 2021-08-06 | Accepted: 2021-08-21

\begin{abstract}
The purpose of this study is to examines how the actualization of the meaning of cooperation in the Koto Petai community. Based on this research, some forms of cooperation in the Koto Petai community, such as: Bampok, recitation on Ramadan night, slaughtering cow on Eid al-Fitr, 'skuduopihak" parties at wedding, etc, are living al-Qur'an and sunnah which has become the custom and culture of the people. The research method is a qualitative study using analytical description method that is describing the data that has been obtained in accordance with the object of research. The object of this research is the local wisdom of the culture of community cooperation in Kerinci Jambi, which is limited to Koto Petai, Danau Kerinci District, Kerinci Regency. The source of research is through observation, interviews with documentation
\end{abstract}

Keywords: Cooperation, Koto Petai, Living Al-Qur'an-Hadist.

Abstrak. Penelitian ini menjelaskan bagaimana aktualisasi makna kerjasama di masyarakat desa Koto Petai. Berdasarkan penelitian ini, beberapa bentuk kerjasama di masyarakat desa Koto Petai, seperti: Bampok, pengajian malam pada malam Ramadan, pemotongan sapi pada lebaran idul fitri, skuduopihak pada acara pernikahan, merupakan Al-Qur'an dan Sunnah yang hidup, yang telah menjadi adat dan budaya masyarakat. Adapun metode penelitian ini adalah penelitian kualitatif dengan menggunakan metode deskripsi analitis yaitu menggambarkan data-data yang telah didapatkan sesuai dengan objek penelitian. Adapun objek penelitian ini adalah kearifan lokal budaya kerjasama masyarakat Kerinci Jambi yang dibatasi pada sebuah desa Koto Petai Kecamatan Danau Kerinci Kabupaten Kerinci. Adapun sumber penelitian adalah melalui observasi, wawancara dan dokumentasi.

Kata Kunci: Kerjasama, Koto Petai, Living Al-Qur'an-Hadis. 


\section{Pendahuluan}

Ilmu living Qur'an-hadis merupakan sebuah ilmu yang yang mengkaji praktik al-Qur'an dan hadis, artinya mengkaji al-Qur'an dari sebuah realita bukan dari ide yang muncul dan penafsiran teks al-Qur'an dan hadis. Sehingga Living Qur'an-Hadis adalah upaya untuk memperoleh pengetahuan yang kokoh dan meyakinkan dari suatu budaya, praktik, tradisi, ritual, pemikiran, atau perilaku hidup di masyarakat yang diinspirasi dari ayat Al-Qur'an dan hadis Nabi. ${ }^{1}$

Al-Qur'an sebagai teks,verbalisasi wahyu Allah, adalah objek utama dalam kajian al-Qur'an, baik itu dari segi bacaan, tulisan, kritik historis, pemahaman, dan pengamalan atau perilaku terhadap al-Qur'an. secara teknis, dengan demikian objek kajian living Qur'an adalah berkenaan dengan perilaku manusia dalam memperlakukan naskah al-Qur'an, bacaan al-Qur'an maupun pengamalannya baik bersifat individual-personal, maupun bersifat komunal. ${ }^{2}$ Dalam bahasanya H.Zuhri adalah dialogue with the qur'an, yang dimaksud dialog al-Qur'an atau mendialogkan al-Qur'an bukan pada konsep dialog yang ada di dalam al-Qur'an, tetapi pada konsep bagaimana pembaca dan pendengar ( teks) al-Qur'an mendialogkan dirinya secara individu maupun kolektif baik dengan perkataan, aksi, ataupun harapan. Oleh karena itu mendialogkkan al-Qur'an berarti melakukan proses eksternalisasi al-Qur'an dengan pembacanya sehingga nilai-nilai al-Qur'an dapat terinternalisasi di dalam diri tiap pembacanya. ${ }^{3}$

Sejarah mencatat sejak periode awal Islam, Nabi sendiri merupakan Maha guru yang mengajarkan al-Qur'an kepada sahabat, sebagian mencatatnya dan menghafalnya ${ }^{4}$, memahamkan dan menjelaskan isi kandungannya kepada sahabatdan adam mambacanya ${ }^{5}$. Nabi mengajak masuk Islam dengan membaca beberapa ayat Qur'an. Abu Bakar membawa teman-teman terdekat menemui Nabi Muhammad, seperti: Uthman bin 'Affan, 'Abdurrahman bin 'Auf, Az-zubair bin Al-awwam, Talha, dan Abi Waqqas, dan lain-lain.

Al-Qur'an yang tidak hanya dijadikan sumber atau dasar dalam menjalani agama Islam. Namun Al-Qur'an membentuk suatu tradisi, budaya bagi masyarakat. Ia memiliki kekuatan super bagi yang mengimani untuk mengubah

${ }^{1}$ Ahmad 'Ubaydi Hasbillah, Imu Living Quran-Hadis: Ontologi, Epistemologi, Dan Aksiologi, 1st ed. (Ciputat: Maktabah Darus-Sunnah, 2019). 22.

${ }^{2}$ Hasbillah. 58.

${ }^{3}$ H. Zuhri, "Mendialogkan Alquran Dengan Pembacanya: Studi Atas Living Qur?An Di Periode Klasik Dan Pertengahan," AL QUDS : Jurnal Studi Alquran Dan Hadis 3, no. 2 (November 25, 2019): 157-84, http://journal.iaincurup.ac.id/index.php/alquds/article/view/030. 164.

${ }^{4}$ Akram Abdu Kholifah addalimi, Jam'u Al-Qur'an: Dirāsah Tabliliyah Limarwiyyabtibi (Beirut: Dar Al-Kitab Alilmiyyah, 2006).21.

${ }^{5}$ Muhammad Abu Syahbah, Madhal Lidiräsatil Qur'an (Saudi Arabia: Dar Al-Liwa, 1987).399. 
kepribadian dan kelompok masyarakat. ${ }^{6}$ Al-Qur'an bukan hanya dalam ritual tetapi juga ada dalam percakapan, praseology, arsitektur, dan seni ${ }^{7}$ sebagaimana yang disebutkan sebelumnya.

Al-Qur'an telah menjadi bagian dari aktivitas kehidupan sehari-hari masyarakat muslim. Bidang arsitektur ayat Al-Qur'an dijadikan hiasan bangunan terutama di dinding masjid. Ingrid Mattson menjelaskan kalimat-kalimat dari ayat $\mathrm{Al}-$ Qur'an telah menyatu dalam budaya Islam sehingga menjadi frasa yang populer $^{8}$, seperti Qs. Al-Baqarah: 156:

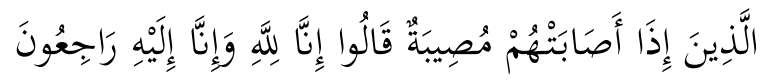

"(yaitu) orang-orang yang apabila ditimpa musibah, mereka mengucapkan: "Inna lillaabi wa innaa ilaibi raaji'uun"'".

Kalimat "Inna lillaabi wa innaa ilaibi raaji'unn" yang seirng diucapkan ketika ada terkena musibah atau ketika mendengar ada yang meinggal, barangkali banyak yang tidak tau bahwa kalimat tersebut merupakan panggalan dari Qs. Al-Baqarah: 156.

Setiap salat sudah pasti umat Islam membaca ayat tertentu dalam rakaatnnya. Bahkan diluar salat umat Islam membaca Al-Qur'an, selain karena AlQur'an menjadi sumber, pedoman hidup umat Islam, tentu karena perintah Allah Swt, seperti dalam Qs. Fathir: $29^{9}$ dan anjuran dari Nabi Muhammad Saw. ${ }^{10}$ 2008). 10

${ }^{6}$ Robert E. Van Voorst, Anthology of World Scriptures (Belmont, CA: Thomson Wasworth,

${ }^{7}$ A. Kevin Reinhart, Lived Islam: Colloquial Religion in a Cosmopolitan Tradition (Cambridge: Cambridge University Press, 2020). 63.

${ }^{8}$ Ingrid Mattson, The Story of The Qur'an, Terj. R.Cecep Lukman Yasin (Jakarta: Zaman, 2013).

${ }^{9}$ Qs. Fathir: 29:

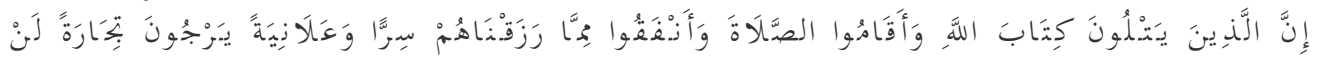

"Sesungguhnya orang-orang yang selalu membaca kitab Allah dan mendirikan shalat dan menafkahkan sebahagian dari rezki yang Kami anuge- rahkan kepada mereka dengan diam-diam dan terang-terangan, mereka itu mengharapkan perniagaan yang tidak akan merugi

${ }^{10}$ HR. At-Tirmidzi:

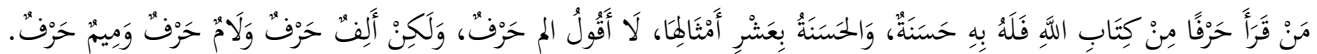

" Barang siapa yang membaca satu huruf dari Al-Qur'an, dia akan memperoleh satu kebaikan. Dan kebaikan itu akan dibalas sepulu kali lipat. Aku tidak mengatakan alif lam mim itu satu huruf, tetapi ali satu huruf, lam satu huruf dan mim satu huruf. (Muhammad bin 'Isa bin Saurah bin Musa AdDahak, At-tirdmidzi Abu 'Isa, Sunan At-Tirmidzi, Juz 5 ( Mesir: Syirkah Maktabah wa Mathba'ah 
Proses mempelajari Kitab Suci yang berjalan bersamaan dengan gelombang manusia yang terlibat dalam penyebarannya, ternyata membuahkan hasil. Banyak para sahabat yang hafal Al-Qur'an. Setelah belajar Al-Qur'an kemudia para sahabat mengajarkan kepada yang lain akan Al-Qur'an: Ibn Mas'ud adalah sahabat pertama yang mengajarkan Al-Qur'an di Mekkah, Mus'ab bin 'Umair dikirim oleh Nabi Muhammad ke Madinah sebagai guru mengaji AlQur'an. bahkan ketika sampai di Madinah Nabi membuat Suffa di dalam masjid yang dijadikan sebagai tempat belajar pemberantasan buta huruf, dengan menyediakan makanan dan tempat tinggal. ${ }^{11}$ Fenomenologi al-Qur'an dan aktivitas bisa diketahu dari pada masa Nabi, Para sahabat menjadikan Al-Qur'an sebagai mahar ${ }^{12}$ dan mengajarkannya kepada istrinya, tilawah tiap bulan. ${ }^{13}$

Penyebaran Islam keberbagai wilayah, ajaran-ajarannya ikut disosialisasikan berbaur dengan budaya lokal wilayah tersebut. Apa yang yang ditradisikan oleh umat Islam di suatu daerah bisa berbeda dengan tradisi umat Islam di daerah yang lain. Islam yang disebar di berbagai wilayah di dunia yang bersifat akulturatif membuatnya mudah beradaptasi dan diterima dengan budaya lokal. Sehingga, corak dan budaya yang berbeda-beda ketika bertemu dengan ajaran Islam membentuk tradisi yang beragam pula. Dalam Konteks Indonesia, Islam disebarkan Islam bertemu dengan tradisi Animisme dan dinamisme. Agama Hindu dan Budha yang lebih dulu singgah di Indonesia juga memberi warna dan membentuk budaya lokal. Dalam rentan waktu yang panjang, akulturasi ajaran Islam dengan budaya lokal mengkristal dan bermetamorfosis menjadi budaya baru. $^{14}$

Dalam hal ini, Ahmad Ubaydi Hasbillah memberikan contoh akulturasi ajaran Islam dan budaya nusantara; misalnya bangunan masjid Menara Kudus, Jawa Tengah terdapat perpaduan antara semangat menghidupkan hadis-hadis tentang membangun masjid, namun juga mempertahankan budaya lokal dalam

Mustafa Al-babi Al-Khalbi, 1975), h. 175. Dan masih banyak hadis yang menjelaskan keutamaan membaca Al-Qur'an sebagaimana dikutip oleh M.M Al A'zami dalam The History of The Qur'anic Text; From Revelation to Compilation .

${ }^{11} \mathrm{M} \mathrm{Al}$ A'zami, The History of The Qur'anic Text; From Revelation to Compilation (Malaysia: IIUM, n.d.). 27-30.

12 Diriwatkan oleh Bukhari bahwa seorang laki-laki yang ingin menikah tapi tidak berkecukupan untuk membeli mahar, maka Nabi menanyakan surah yang ia hafal kemudian menjadikan surah itu sebagai mahar (Muhammad Abu Syahbah, Madhal Lidirāsatil Qur'an (Saudi Arabia: Dar Al-Liwa', 1987)), h. 399.

${ }^{13}$ Akram Abdu Kholi >fah addalimi, Jam'u Al-Qur'an: Dirāab Tabliliyah Limarwiyyabtibi. 26.

${ }^{14}$ Hasbillah, Ilmu Living Quran-Hadis: Ontologi, Epistemologi, Dan Aksiologi. 352-353. 
segi arsitekturnya. ${ }^{15}$ Bahkan Hasbillah menyebutkan bahwa arsitektur Masjid Menara Kudus bukanlah sekedar bentuk akulturasi biasa, tetapi dikategorikan sebagai bentuk sinkretisme, yakni; suatu proses perpaduan dari beberapa paham atau aliran agama dan kepercayaan. Sinkretisme ini terjadi karena adanya keinginan untuk menggabungkan dua hal yang berbeda dengan cara melakukan sebuah analogi atau "penyamaan" atas beberapa unsur penciri tradisi, terutama dalam hal teologi dan mitologi agama. Biasanya terjadi pada musik, sastra, arsitektur, dan ekspresi budaya. ${ }^{16}$ Sehinggadalam hal ini nilai-nilai yang terkandung dalam alQur'an terejawantah dalam kehidupan sehari-hari.

Sebelum Nabi Muhammad meletakkan sendi-sendi kebudayaan Islam di Madinah, nilai kebudayaan Islam telah dirintis dengan sekelompok orang-orang Madinah, perihal pentingnya kehidupan yang membedah tata kehidupan manusia, yang semula terhadang dengan sekat kesukuan menjadi ruang lebih luas sebagai negara bangsa. Perjuangannya telah membawa pengaruh mendalam seputar persaudaraan, baik sesama muslim ataupun persaudaraan dengan non muslim yang telah tinggal di Madinah sebelum kedatangan Nabi dan para sahabat. Selain membangun persaudaraan yang tak diskriminatif, kepeloporan Nabi dalam persamaan dan kesetaraan merupakan budaya baru dalam kehidupan masyarakat Arab, sehingga orang Arab sejajar| kedudukannya, pun perbedaan ras yang acap kali menjadi sebab terjadinya perpecahan dan permusuhan dilenyapkan. Sifat tolong menolong dan melindungi "yang itu telah menjadi ciri masyarakat Arab" berangkat dari lingkup kecil diperluas dengan dasar nilai kemanusiaan dan persamaan. $^{17}$

${ }^{15}$ Akulturasi budaya ini tidak terjadi hanya di Indonesia bahwa di berbagai wilayah. Ingrid Mattson menjelaskan bahwa Di berbagai wilayah dunia Islam, kaum muslimin yang mengadopsi unsur-unsur arsitektur keagamaan lokal untuk diterapkan dimasjid. Di pusat dunia Islam, kubah gaya bizantium menjadi pilihan, tentu saja karena bentuknya sangat efektif untuk membangkitkan sensasi keagungan (dalam istilah tasawuf "basth") dalam diri orang yang salat, terutama di daerah yang cuacanya menuntut mereka membangun gedung dengan atap yang tertutup rapi setidaknya pada bulan terntentu. Menara persegi panjang di Syria, Afrika, dan Andalusia Islam bisa jadi terinspirasi oleh menara lonceng gereja. Di daratan Cina, pengaruh arsitektur kuil Budha terlihat pada sisi tempat salat yang ditinggikan, sehingga orang yang salat merasakan sensasi naik kehadirat Tuhan. Singkatnya kaum muslim masa awal mengadopsi berbagai unsur arsitektur keagamaan masyarakat lokal. Sementara pada saatyang sama tetap mempertahankan struktur utama masjid Nabi di Madinah dan menghindari gambar atau patung yang melukiskan wujud Tuhan. Sebagai gantinya mereka melukiskan Al-Qur'an. (Ingrid Mattson, The Story of The Qur'an, terj. R.Cecep Lukman Yasin (Jakarta: Zaman, 2013), h.216.

${ }^{16}$ Hasbillah, Ilmu Living Quran-Hadis: Ontologi, Epistemologi, Dan Aksiologi. 212-213.

${ }^{17}$ Khoiro Ummatin, "Tiga Model Interaksi Dakwah Rasulullah Terhadap Budaya Lok," Jurnal Dakwah 15, no. 1 (2014): 195-96, https://doi.org/10.14421/jd.2014.15109. 
Tulisan ini ingin membahas kearifan lokal budaya kerjasama tentunya berlandaskan al-Qur'an dan hadis sebagai sumber ajaran Islam. Islam mengandung dua hal yang inheren: pertama, Islam dimaknai sebagai ajaran dan ajarannya tidak hanya mencakup kepercayaan dan ritus saja, akan tetapi juga menjadi dasar bagi pembentukan peradaban. Kedua, Islam dimaknai sebagai realitas historis para pemeluknya. ${ }^{18}$ Sebagaimana yang disebutkan di awal bahwa objek dalam kajian living al-Qur'an, baik itu dari segi bacaan, tulisan, kritik historis, pemahaman, dan pengamalan atau perilaku terhadap al-Qur'an. Seperti Artikel; Frederick Mathewson Denny: A tradition of Oral Permonce and Transmission ${ }^{19}$; Living Qur'an di Tanah Kaili (Analisis Interaksi Suku Kaili Terhadap Alquran dalam Tradisi Balia di Kota Palu, Sulawesi Tengah) ${ }^{20}$; Zulfikar, E. Living Quran: Konstruksi Metode Tahfidz Al-Quran Di Majelis Qiraah Wat Tahfidz Pondok Pesantren Murattil Al-Quran Lirboyo Kota Kediri ${ }^{21}$; Muhammad Shaleh Assingkily et al., "Living Qur'an Dan Hadis Di MI Nurul Ummah (Rutinitas, Ritual Ibadah Dan Pembinaan Akhlak) ${ }^{22}$; Tradisi Yasinan (Kajian Living Qur'an Di Ponpes Ngalah Pasuruan) ${ }^{23}$; Aziz, Inspirasi Alquran Dan Kearifan Lokal Untuk Meningkatkan Profesionalitas Tenaga Kerja ${ }^{24}$. Untuk itu, dalam tulisan ini penulis membahas bagaimana ibya alsunnah tentang ta'awun (kerjasama/tolongmenolong) yang ada di masyarakat Desa Koto Petai.

Di Provinsi Jambi sangat kental solidaritas antar masyarakatnya, Jambi mempunyai seloko yang berbunyi "kecik dan besebut namo, besak dan besebut

18 Abdul Wahid Hasan,dkk, Studi Islam Kontemporer Perspektif Insider/outsider (Yogyakarta: IRCiSoD, 2017), 262.

${ }^{19}$ Frederick Mathewson Denny, “Qur'ān Recitation: A Tradition of Oral Performance and Transmission," Oral Tradition, 1989, 5-26, https://mospace.umsystem.edu/xmlui/handle/10355/65410.

20 "Living Qur'an di Tanah Kaili (Analisis Interaksi Suku Kaili Terhadap Alquran dalam Tradisi Balia di Kota Palu, Sulawesi Tengah)," Nun : Jurnal Studi Alquran dan Tafsir di Nusantara 3, no. 1 (July 2018): 61-87-87, https://doi.org/10.32459/nun.v3i1.15.

${ }^{21}$ Eko Zulfikar, "Living Quran: Konstruksi Metode Tahfidz Al-Quran Di Majelis Qiraah Wat Tahfidz Pondok Pesantren Murattil Al-Quran Lirboyo Kota Kediri," MAGHZA: Jurnal Imu Al-Qur'an Dan Tafsir 4, no. 1 (June 19, 2019): 74-94, https://doi.org/10.24090/MAGHZA.V4I1.2383.

${ }^{22}$ Muhammad Shaleh Assingkily et al., "Living Qur'an Dan Hadis Di MI Nurul Ummah (Rutinitas, Ritual Ibadah Dan Pembinaan Akhlak)," AR-RLAYAH : Jurnal Pendidikan Dasar 4, no. 1 (June 30, 2020): 27-44, http://journal.iaincurup.ac.id/index.php/JPD/article/view/1402.

23 "Tradisi Yasinan (Kajian Living Qur'an Di Ponpes Ngalah Pasuruan) | Mafhum,"

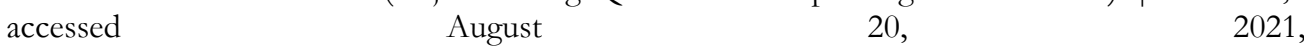
https://jurnal.yudharta.ac.id/v2/index.php/mafhum/article/view/1612.

${ }^{24}$ Aziz "Inspirasi Alquran Dan Kearifan Lokal Untuk Meningkatkan Profesionalitas Tenaga Kerja | Aziz | AL QUDS : Jurnal Studi Alquran Dan Hadis,” accessed August 20, 2021, http://journal.iaincurup.ac.id/index.php/alquds/article/view/07/pdf. 
gela"25 ungakapan ini berarti tidak ada perbedaan antara si kaya dan si miskin. Hal ini sesuai dengan hadis Nabi:

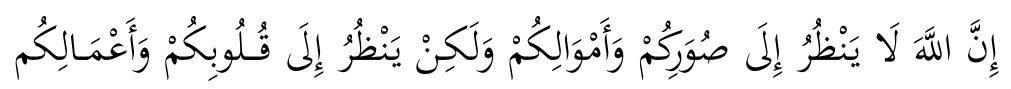

Sungguh Allab tidak melihat rupa dan harta kalian, melainkan melihat hati dan amal kalian." 26

Tidak heran jika adat-adat di Jambi berdasarkan al-Qur'an dan Hadis, karena Jambi sendiri memiliki prinsip, adat bersendikan syara', syara' bersendikan kitabullah. ${ }^{27}$ Kearifan lokal ${ }^{28}$ telah banyak digunakan dalam banyak aspek kehidupan. Kearifan lokal berarti hubungan harmonis antara manusia, alam dan lingkungan binaan di daerah yang ada juga dipengaruhi oleh budayanya meskipun

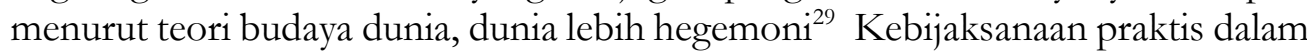
perawatan kesehatan telah dipelajari selama berabad-abad di Amerika Serikat. Soedigyo dkk meyebutkan dua unsur utama kearifan lokal: manusia, beserta coraknya pikiran, alam dan iklim. Pola pikir manusia menghasilkan kebijaksanaan dalam menyusun pengetahuan yang dianggap baik untuk kehidupan mereka, seperti hukum adat, pemerintahan, dan prosedur untuk aktivitas keseharian mereka. Berdasarkan unsur-unsur ini, Soedigyo dkk, membedakan kearifan lokal dalam dua bentuk, pertama nyata; kearifan lokal diwujudkan dalam bentuk tulisan dan bangunan. Kedua, adalah tidak berwujud, pengetahuan lokal yang tidak berwujud dapat ditemukan dalam nasehat yang disampaikan secara verbal dan turun temurun melalui nyanyian balda yang berisi ajaran tradisional. ${ }^{30}$

Lebih jauh adapun rumusan masalah dalam penelitian ini adalah bagaimana bentuk-bentuk budaya kerjasama antar masyarakat Desa Koto Petai

${ }^{25}$ Yudi Armansyah Fakultas et al., "Kontribusi Seloko Adat Jambi Dalam Penguatan Demokrasi Lokal" 14, no. 1 (2017); author Nurhasanah, "Makna Simbolik Seloko Adat Jambi (Suatu Tinjauan Filosofis)" (Universitas Indonesia, 2004), http:/ /ib.ui.ac.id.

${ }^{26}$ Imam Abi Husain Muslim bin Al-Khajjaj An-Nasaaiburi, Sabib Muslim (Kairo: Daar AlHadith, 1991). 1987.

${ }^{27}$ Fakultas et al., "Kontribusi Seloko Adat Jambi Dalam Penguatan Demokrasi Lokal"; Nurhasanah, "Makna Simbolik Seloko Adat Jambi (Suatu Tinjauan Filosofis)."

${ }^{28}$ Irmayanti Meliono, "Understanding the Nusantara Thought and Local Wisdom as an Aspect of the Indonesian Education," TAWARIKH 2, no. 2 (2011): 2, https://doi.org/10.2121/tawarikh.v2i2.392., Bevaola Kusumasari, Quamrul Alam, "Local wisdom-based disaster recovery model in Indonesia," Disaster Prevention and Management: An International Journal 21, no. 3 (1 Januari 2012): 351-69, https://doi.org/10.1108/09653561211234525.

${ }^{29}$ Kathryn Anderson-Levitt, Local meanings, global schooling: Anthropology and world culture theory (Springer, 2003).

${ }^{30}$ Doddy Soedigdo, Ave Harysakti, dan Tari Budayanti Usop, "Elemen-elemen pendorong kearifan lokal pada arsitektur nusantara," Jurnal Perspektif Arsitektur 9, no. 1 (2014): 38-39. 
yang merupakan aktualisasi dari Al-Qur'an dan Hadis? Untuk menjawab pertanyaan tersebut maka penelitin ini menggunakan metode penelitian kualitatif dengan menggunakan metode deskripsi analitis yaitu menggambarkan data-data yang telah didapatkan sesuai dengan objek penelitian. Adapun objek penelitian ini adalah kearifan lokal budaya kerjasama masyarakat Kerinci Jambi yang dibatasi pada sebuah Desa Koto Petai Kecamatan Danau Kerinci Kabupaten Kerinci. Adapun sumber penelitian adalah melalui observasi, wawancara dan dokumentasi.

Observasi dilakukan di mana peneliti secara lansung turun ke lapangan yang dalam hal ini dilakukan di desa Koto Petai. Peneliti mengamati perilaku dan aktivitas individu-individu di lokasi penelitian. Dalam penelitian ini peneliti merekam dan mencatat-baik dengan cara terstruktur maupun semistruktur.

Untuk tahap awal peneliti mengamati (dan mengajukan sejumlah pertanyaan yang memang ingin diketahui oleh peneliti), aktivitas-aktivitas di lokasi penelitian, observasi tahap awal ini dilaksanakan dalam penulisan penelitian ini, yakni tahun 2020 lalu.

Wawancara merupakan bentuk komunikasi antara dua orang, melibatkan seseorang yang ingin memperoleh informasi dan material lainnya dengan mengajukan pertanyaan-pertanyaan berdasarkan tujuan tertentu. ${ }^{31}$ Dalam hal ini peneliti mewancarai informan yang telah ditetapkan pada subjek penelitian, namun pertanyaan-pertanyaan ini masih secara umum dan tidak terstruktur dan bersifat terbuka yang dirancang untuk memunculkan pandangan dan opini dari para informan. Informan ini adalah Kepala Desa, Buya (tokoh agama), serta masyarakat yang dianggap memiliki pengetahuan tentang tradisi kerjasama di desa Koto Petai.

Selain observasi dan wawancara, peneliti juga mengumpulkan dokumendokumen baik dokumen publik seperti koran, makalah, laporan, dan lain-lain. Atau memungkinkan juga dokumen privat seperti buku harian, diary, surat. Untuk melengkapi data-data yang dubutuhkan peneliti juga mengumpul literatur-literatur dari berbagai sumber, seperti perpustakaan perpustakaan, jurnal, buku-buku, dan lain-lain yang terkait. Dengan meode demikian diharapkan mampu untuk menjelaskan tujuan penelitian ini, yakni menjelaskan aktualisasi makna kerjasama di masyarakat Desa Koto Petai.

\section{Islam dan Kerjasama}

Dalam menciptakan manusia, Tuhan menjadikan berkelompok sosial itu sebagai keharusan. Dengan begitu masyarakat memenuhi doktrin kesatuan eksistensial. Selain dari itu, al-Qur'an mengatakan bahwa manusia itu lemah dan

${ }^{31}$ Deddy Mulyana, Metode Penelitian Kualitatif: Paradigma Baru Ilmu Komunikasi dan Ilmu Sosial Lainnya (Bandung: PT Remaja Rosdakarya, 2006), 145. 
selalu menghadapi godaan. Kalau ia tunduk kepada godaan-godaan itu, ia menjadi jahat dan agresif. Masyarakat memaksanya untuk mengatasi nafsunya. Oleh karena manusia itu merdeka, maka untuk menyusun suatu masyarakat memerlukan persetujuan timbal balik. Tetapi dasar untuk berpegang kepada "kontrak sosial" yang akan menjelaskan kewajiban-kewajiban dan menjamin hak masing-masing tidak dapat diekspresikan hanya dengan suatu persetujuan antara kemauankemauan yang merderka tentang suatu tujuan yang belum terbatasi, akan tetapi memenuhi keperluan yang timbul dari watak manusia. Persetujuan antara kemauan-kemauan itu tetap bersandar kepada satu norma yang lebih tinggi, yaitu Tuhan. Dalam perspektif nyata bahwa menolak pertisipasi dalam kelompok itu nampak sangat tercela. ${ }^{32}$

Semua agama menganggap kerjasama sebagai salah satu nilai kemanusiaan terpenting yang menjadi landasan kesejahteraan masyarakat dan keberlanjutannya. Islam mendorong kerjasama antara individu dan negara untuk memastikan kehidupan yang layak bagi semua orang dengan bekerjasama dalam hal yang baik dan memberikan bantuan kepada mereka yang membutuhkannya.

Allah berfirman dalam Qs. Al-Maidah: 2 :

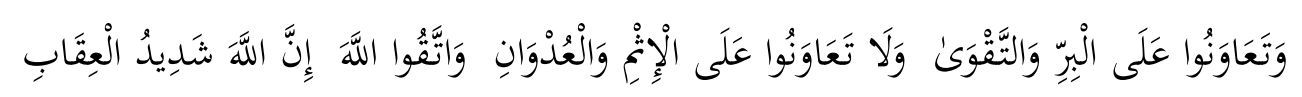

"Dan tolong-menolonglah kamu dalam (mengerjakan) kebajikan dan takwa, dan jangan tolong-menolong dalam berbuat dosa dan pelanggaran. dan bertakwalah kamu kepada Allah, Sesunggubnya Allah Amat berat siksa-Nya".

Istilah tolong menolong atau kerjasama yang ada di dalam al-Qur'an terkadang digunakan istilah ta'awun, dan kadang juga digunakan istilah ista'ana. Ta'awun atau tolong menolong adalah ciri kehalusan budi, kesucian jiwa, ketinggian akhlak dan membuahkan cita antara teman dan penuh solidaritas serta penguat persahabatan. ${ }^{33}$ Kerjasama berarti berkerja bersama-sama, tidak sendirian, lebih dari satu orang, lebih dari satu lembaga, institusi bahkan negara. Tidak ada seseorang yang tidak membutuhkan yang lain, tidak ada lembaga yang tidak membutuhkan lembaga lain, tidak ada institusi yang tidak membutuhkan istitusi yang lain, bahkan tidak ada Negara yang tidak membutuhkan Negara lain.

Kerjasama bisa dilaksanakan antarindividu dengan individu, antarinstitusi dengan institusi, antarlembaga dengan lembaga dan bahkan dalam skop yang paling besar antara negara dengan negara lain. Kerjasama dilakukan untuk

\footnotetext{
32 Marcel A Boisard, Humanisme dalam Islam (Jakarta: Bulan Bintang, 1980), 108.

${ }^{33}$ Irfan Irfan, "Konsep Al-Mu'awanah Dalam Al-Qur'an (Suatu Kajian Tafsir Tematik)," AL-TADABBUR 6, no. 2 (December 10, 2020): 279-91, http://journal.iainternate.ac.id/index.php/altadabbur/article/view/366.
} 
kemaslahatan dan pencapaian tujuan bersama, tidak ada individu, istitusi, lemabaga bahkan Negara yang dapat eksis tanda yang lain. Negara adikuasa (super power) dalam memenuhi kebutuhan dan ketahanan energinya misalnya melakukan kontrak kerjasama dengan negara-negara timur tengah, bahkan juga dengan Indonesia seperi pertambangan tembaga, bejih besi, dll.

Kerjasama mempunyai mamfaat yang sangat besar baik secara individu, lembaga, instusi dan Negara. kerjasama dapat menutupi kekurangan bersama, dan mempermudah serta mempercepat pencapaian tujuan bersama, Perusahaan penerbangan raksasa seperti Boing USA dan Airbus Eropa dalam memproduksi pesawat juga melibatkan banyak perusahan dalam memproduksi pesawat. PT Dirgantara Indonesia pernah mendapatkan kontrak kerjasama dengan kedua perusahaan raksasa tersebut. Dalam penelitian, ta'awun bisa mengentas kemiskinan di Kota Makasar. ${ }^{34}$

Dalam teori sosiologi akan dapat dijumpai beberapa bentuk kerjasama yang biasa diberi nama kerjasama (cooperation). Kerjasama tersebut lebih labjut dibedakan lagi dengan: Kerjasama spontan (spontaneous cooperation), kerjasama lansung (directed cooperation), kerjasama kontrak (contractual cooperation) dan kerjasama tradisional (traditional cooperation). Kerjasama spontan adalah kerjasama yang serta merta. Kerjasama lansung merupakan hasil dari perintah atasan penguasa, sedangkan kerjasam kontrak merupakan kerjasama atas dasar tertentu, dan kerjasama traditional merupakan bentuk kerjasama sebagian bagian atau unsur dari system sosial. ${ }^{35}$

Biasanya juga dibedakan antara gotong-royong dengan tolong-menolong. Gotong royong digambarkan dengan istilah "gugur gunung" (bahasa jawa) dan tolong menolong adalah "sambat sinambat". Keduanya merupakan unsur-unsur kerukunan. Beberapa pendapat menyatakan bahwa pada masyarakat di mana bentuk kerjasama merupakan unsur sistem nilai-nilai sosialnya sering kali dijumpai keadaan-keadaan di mana di mana warga-warga masyarakat tersebut tidak mempunyai inisiatif ataupun daya kreasi karena perorangan terlalu mengandalkan pada bantuan dari rekan-rekannya. Terlepas dari apakah terrdapat akibat akibat positif dan negatif, kerjasama sebagai salah satu bentuk interaksi sosial merupakan gejala universal yang ada pada masyarakat di manapun juga, walaupun secara tidak sadar kerjasama tadi mungkin timbul terutama di dalam keadaan-keadaan di mana kelompok tersebut mengalami ancaman dari luar. ${ }^{36}$

34 Zulkarnain, Abdul Wahab, and Syaharuddin Syaharuddin, "Peran Ta'awun Dalam Mengentas Kemiskinan Di Kota Makassar," Al-Bubuts 16, no. 2 (December 31, 2020): 1-16, https://doi.org/10.30603/AB.V16I2.1755.

${ }^{35}$ Soerjono Soekanto dan Budi Suliasto, Sosiologi Suatu Pengantar (Jakarta: Rajawali, 2013), 67.

${ }^{36}$ Soerjono Soekanto dan Budi Suliasto, 68. 
Dalam sejarah Islam kita bisa menemukan bagaimana Rasulullah menanamkan nilai persaudaraan pada umat muslim, bahkan kepada non-muslim, Ketika Hijrah ke Madinah Rasulullah membangun masjid di Quba dibantu oleh para sahabat. ${ }^{37}$

Nabi Muhammad Saw mempersaudarakan kaum muhajirin dengan kaum Anshar, maka setiap orang madinah mengambil salah seorang muhajirin sebagai saudaranya dan mengajaknya pulang ke rumah mereka, dan mereka berbagi apa saja yang mereka miliki. ${ }^{38}$ Persaudaraan dalam Islam memiliki tujuan melenyapkan persaingan antar suku, sombong, ego, menghidupkan semangat saling membantu, bekerjasama dan saling mencintai karena Allah Swt dan Rasul-Nya. ${ }^{39}$

Rasulullah Saw mempersaudarakan sahabatnya dalam kalangan orangorang muhajirin dan Anshar. Antaranya ialah ja'far bin Abi Thalib dengan Mu'az bin Jabal, Hamzah bin Abdul Muthalib dengan Zaid bin Harisah, Abu Bakar Assiddiq dengan Kharrij bin Zuhair, Sa'ad bin Al-Ruba'i dengan Adurrahman bin Auf dll. ${ }^{40} \mathrm{Sa}$ 'ad bin Ruba'i menawarkah separuh hartanya yaitu rumah, harta dan ahlinya dengan seksama kepada saudaranya yaitu Abdurrahman bin Auf, namun sebaliknya, Abdurrahman bin Auf berterimakasih dan meminta Sa'ad bin Ruba'i membawanya ke pasar untuk bekerja di sana. ${ }^{41}$

Begitu pula tradisi kerjasama/gotong royong di masyarakat Desa Koto Petai, ketika diwawancara kepala Desa (Kasim), apakah bentuk gotong royong ini merupakan aplikasi dari Al-Qur'an dan Hadis? Tentu berdasarkan Al-Qur'an dan hadis, karena adat di Desa Koto Petai, adat yang yang bersendi syarak, syarak bersendi kitabullah, artinya, syarak mengato adat memakai. ${ }^{42}$

Ada banyak sekali ayat dan hadis yang menganjurkan untuk bekerjasama/gotong royong:

QS. At-Taubah: 71.

${ }^{37}$ Ibnu Hisyam, Assiratu An-Nabawiyyatu (Beirut: Dar Al-Kitab Al-Arabi., 1990), 136.

${ }^{38}$ Mustafa As-Shiba'i, Al-Sirah Al-Nabawiyab: Durusun Wa' Ibarun (Cairo: Dar Al-salam, 2016), 38 .

${ }^{39}$ Muhammad Azhim, At-Takbtith lil Al-hijrah Mabadi' Ilmiyah wa Ilhamă Rabbaniyah (Cairo: Dar At-tawzi' Wa An-nasyr Al-Islamiyah, 2004), 88.

${ }^{40}$ Muhammad Sa'id Ramadhan Al-Buthy, Sirah Nabawiyab : kajian mendalam manhaj gerakan Islam pada masa Rasulullah (s.a.w.) / Dr.Mubammad Sa'id Ramadhan Al-Butby. (Pustaka Dini Sdn. Bhd., 2001), 175. 2008), 283.

${ }^{41}$ Muhammad Sa'id Ramadhan Al-Buthin, Fiqih Al-Sirah (Selangor: Dewan Pustaka fajar,

${ }^{42}$ Kasim (Kepala Desa Koto Petai, Wawancara 20 April 2020 


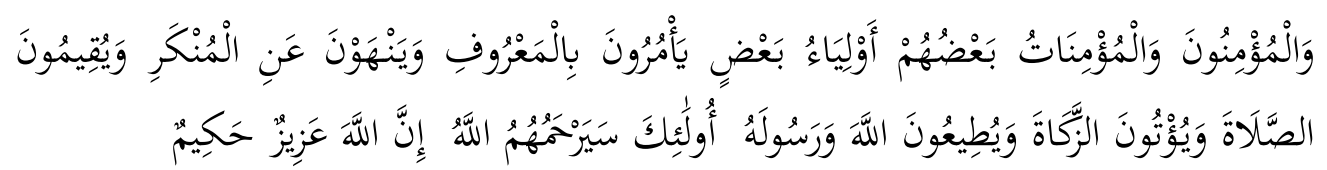

"Dan orang-orang yang beriman, lelaki dan perempuan, sebahagian mereka (adalab) menjadi penolong bagi sebahagian yang lain. mereka menyurub (mengerjakan) yang ma'ruf, mencegah dari yang munkar, mendirikan shalat, menunaikan zakat dan mereka taat pada Allah dan Rasul-Nya. mereka itu akan diberi rahmat oleh Allab; Sesunggubnya Allah Maha Perkasa lagi Maha Bijaksana.

HR. Bukhari dan Muslim.

$$
\text { مَنْ كَانَ فِي حَاجَةِ أَخِيَهِ كَانَ اللهُ فِي حَاجَتِهِ } 43
$$

Barang siapa menolong saudaranya, make Allah akan selalu menolongnya.

\section{Kerjasama dalam Tradisi Masarakat Lokal Desa Koto Petai Kerinci Jambi}

\section{Masarakat Lokal Desa Koto Petai Kerinci Jambi}

Desa Koto Petai kecamatan Danau Kerinci adalah salah satu desa yang terletak di lembah kerinci, secara struktural desa ini dipimpin oleh kepala desa yang merupakan bawahan dari Camat dan Bupati. Secara kultural desa ini dipimpin oleh ninik mamak yang bertugas memimpin dan mengatasi masalah yang terdapat pada anak jantan dan anak betino dalam keturunan ninik mamak tersebut.

Secara geografis desa ini sebelah utara berbatasan dengan desa Koto Salak, Sebelah selatan dengan hamparan Danau Kerinci, sebelah timur dengan desa Tanjung Tanah dan sebelah barat dengan Desa Ujung Pasir.

Sebagian besar penduduk Desa Koto Petai berkerja sebagai petani ketika berada di desa Kotopetai dan sebagai buruh migran (TKI) di Malaysia ketika berada di luar negeri, mereka duduk di pelosok Malaysia dengan berbagai latar belakang pekerjaan: sebagai buruh bangunan, cleaning Servis dan pembantu rumah tangga, bahkan ada di antara mereka yang telah menjadi penduduk tetap dengan mendapatkan IC merah, walaupun bertempat tinggal seadanya di perantauan mereka dapat merubah nasib mereka setelah mereka pulang kampong, dengan mendirikan rumah tempat tinggal mereka setelah tidak bekerja sebagai buruh

43 Abi Abdullah Muhammad bin Ismail Al-Bukhari, al-Jami As-Sabih Al-Musnad alMukbtasar min Umur Rasulilah SAW wa Sunanibi wa Ayyamibi, vol. 3 (Kairo: Matba'at As-salafiyyah, 1400), 128., An-Nasaaiburi, Sabih Muslim, 1996. 
migran, membeli sawah dan kebun dan menyekolahkan anak mereka hingga sampai di perguruaan tinggi.

Menurut cerita dari orang tua bahwa warga Desa Koto Petai telah merantau ke Malaysia sejak awal tahun 1905 sebelum Indonesia merdeka, banyak warga Desa Koto Petai yang berangkat naik haji ke Mekah terlebih dahulu merantau ke Malaysia dengan pekerjaan menyadap karet dan setelah mempunyai bekal yang cukup mereka menunaikan ibadah haji dan kembali ke Desa Koto Petai atau menetap kembali di Malaysia. Bahkan keturunan warga Desa Koto Petai di Malaysia telah mempunyai perkampungan yang bernama Sungai lui Batu 20 disini banyak warga keturunan Desa Koto Petai dan Tanjung Pauh. Jarak perkampungan ini kurang lebih 15 kilometer dari Kuala Lumpur.

Selain berkerja sebagai petani dan buruh migran masyakat Desa Koto Petai juga berkerja sebagai Pegawai Negeri Sipil, guru, sebagian kecil pedagang dan nelayan kecil.

Warga Desa Koto Petai pada era tahun 80-an rata-rata tamatan sekolah dasar hanya sebagian kecil tamatan sekolah menengah atas dan hanya bilangan jari yang sampai perguruan tingggi. Pada saat ini sudah banyak warga Desa Koto Petai yang berpendidikan SI dan beberapa orang yang berpendidikan S2 dan S3.

\section{Bentuk-Bentuk Kerjasama dalam Tradisi Masyarakat Desa Koto Petai Kabupaten Kerinci.}

Al-Qur'an dan Hadist merupakan sumber atau pedoman dalam kehidupan umat Islam. Keduanya merupakan tuntunan untuk beragama. Ketika Ibunda Aisyah r.a menjawab bagaimanakah Akhlak Rasulullah, maka beliau menjawab akhlah Rasullullah adalah Al-Qur'an "Kana khuluquhū al-Qur'an". Ini menunjukkan bahwa apapun yang dilakukan oleh Nabi merupakan artikulasi dari Al-Qur'an. sedangkan segala perbuatan yang dilakukan Nabi sendiri tidak lain adalah sunnah, dalam terminologi hadis. Oleh karena itu, sunnah direkam oleh ahli hadis secara sangat detail, tanpa ada pembedaan mengandung kehujahan dalam hukum atau tidak. Dijadikan landasan hukum maupun tidak. ${ }^{44}$

Kemudian pada masa sahabat, menghidupkan Al-Qur'an (living the Qur'an) adalah menghidupkan sunnah Nabi (living the Sunnab), yaitu menghidupkan tradisi kenabian. Cara sahabat menghidupkan Al-Qur'an adalah dengan meneladani, mengikuti jejak Nabi. Ada banyak cara sahabat meneladani Nabi untuk menghidupkan Al-Qur'an. semuanya bergantung pada pengalaman masingmasing dalam berinteraksi dengan Nabi. Seecara umum dapat disimpulkan bahwa

\footnotetext{
${ }^{44}$ Ahmad 'Ubaydi Hasbillah, Ilmu Living Quran-Hadis: Ontologi, Epistemologi, dan Aksiologi (Ciputat: Maktabah Darus-Sunnah, 2019), 4.
} 
pada masa sahabat, menghidupkan al-Qur'an tidak semata merta dilakukan secara lansung dari al-Qur'an. Melainkan dari keteladanan terhadap tradisi kenabian (sunnab nabawiyyah). Kalaupun ada kasus menghidupkan al-Qur'an secara lansung, pasti hal itu telah mengalami penelaahan terlebih dahulu dari memori para sahabat terkait tradisi kenabian tersebut. ${ }^{45}$

Berkembangnya Islam di seluruh dunia diiringi dengan penanaman ajaran Islam yang berdasarkan Al-Qur'an dan Sunnah. Pola hidup masyarakat dalam kesehariannya dituntun oleh keduanya. Sebagai juga yang terdapat di Desa Koto Petai. Berbagai adat istiadat, bahkan kebiasaan sehari-hari merupakan adopsi dari ajaran Islam. Salah satunya adalah budaya kerjasama. Ada beberapa bentuk kerjasama dalam masyarakat Koto Petai, landasannya tidak lain adalah berdasarkan Al-Qur'an dan Hadis sebagaimana yang telah disampaikan. Kemudian penerapan ajaran ini telah dilaksanakan terus menurus sehingga menjadi adat dan budaya Desa Koto Petai. Bentuk-bentuk kerjasamanya adalah sebagai berikut:

\section{Dalam Bidang Pertanian}

Secara georafis Desa Koto Petai merupakan daerah pertanian terutama sawah sedangkan ladang sudah tidak diolah dengan baik sejak 30 tahun yang lalu dikarenakan alasan keamanan. Sejak awal dalam melakukan pertanian masyarakat Desa Koto Petai telah melakukan kerjasama dimulai dari persiapan turun ke sawah di mana mereka bekerjasama membersihkan saluran irigasi (Ringko) agar air dapat tersalur dengan baik atau lainnya, seperti membuka jalan.

Di awal masa turun ke sawah biasanya pemerintah desa memerintahkan untuk menyemai benih secara bersama-sama dengan harapan ketika panen juga bersama-sama. Hal ini berguna untuk menanggulangi hama seperti tikus, belalang dan lainnya. Dalam mengerjakan sawah baik laki maupun perempuan juga saling berkelompok antara 3-10 orang, di mana mereka setiap hari bergilir mengerjakan sawah masing-masing anggota kelompok, bisanya laki bekerjasama dalam menebas rumput, mencangkul sawah, dan mengakat padi dari sawah ke rumah ketika panen, sedangkan perempuan bekerjasama dalam menanam padi, menyiang dan panen. Istilah ini dalam istilah bahasa Kerinci Desa Koto Petai disebut Bampok. ${ }^{46}$

${ }^{45}$ Ahmad 'Ubaydi Hasbillah, 5-6.

${ }^{46}$ Istilah Bampok merupakan istilah yang digunakan masyarakat koto petai dalam hal kerja sama dalam bidang pertanian (sawah), di mana sitilah ini mengandung pengertian bahwa beberapa orang saling bergiliran mengerjakan sawah. Misalkan : si A membantu si B menanam padi, pada lain kesempatan si B membantu si A menanam padi lagi tanpa ada upah. 


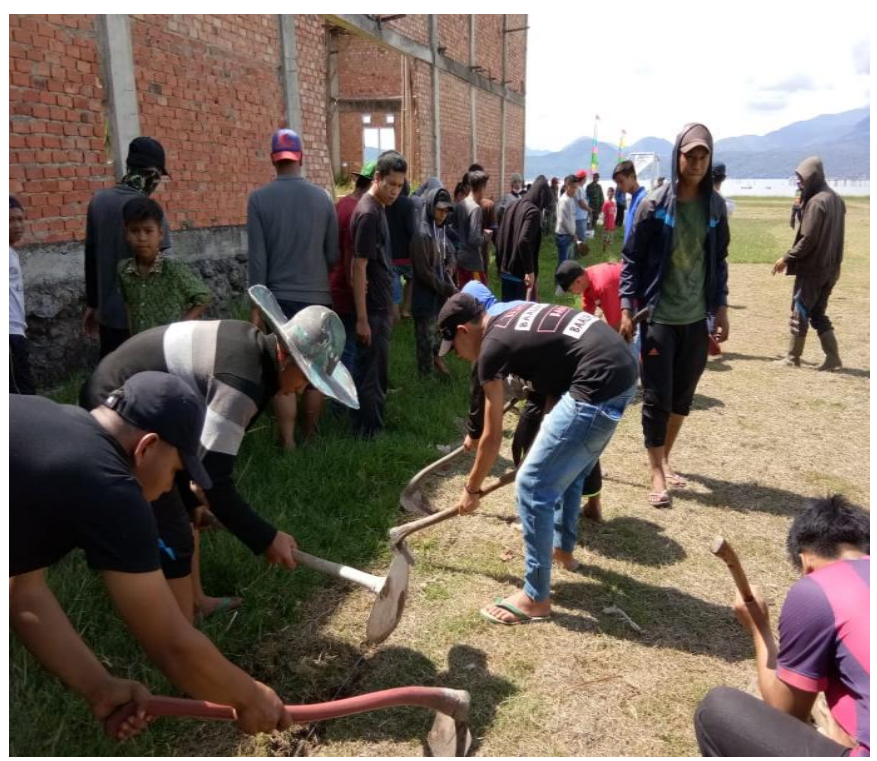

Gambar 1. Kegiatan Ringko Desa Koto Petai

Sumber: Dokumentasi Desa

2. Pernikahan

Setelah anak mereka baik laki dan perempuan menginjak dewasa dan menemukan jodohnya maka pernikahan dan resepsi dilaksanakan. Untuk mempersiapkan pernikahan dan resepsi terlihat adanya kerjasama dimulai dari pengumpulan keluarga kedua mempelai baik laki laki maupun perempuan (skuduopihak) dalam pertemuan tersebut disepakati pembagian tugas masing baik tugas pelaksanaan pernikahan sampai kebutuhan resepsi pernikahan

Sebelum acara pernikahann dimulai biasanya 3 hari sebelum itu kaum perempuan berkumpul di rumah mempelai perempuan mempersiapkan bumbu bumbu masakan sambil membawa beras, kelapa, gula, kopi, garam dan lain yang disebut petoloh. Sedang laki-laki berkumpul satu hari sebelum acara untuk mempersiapkan akomodasi dan dilanjutkan pada malam hari untuk membantu mengupas serabut kelapa, memarut dan memeras kelapa untuk santan, setelah itu dilanjukan dengan ibuk-ibuk memasak gulai. 


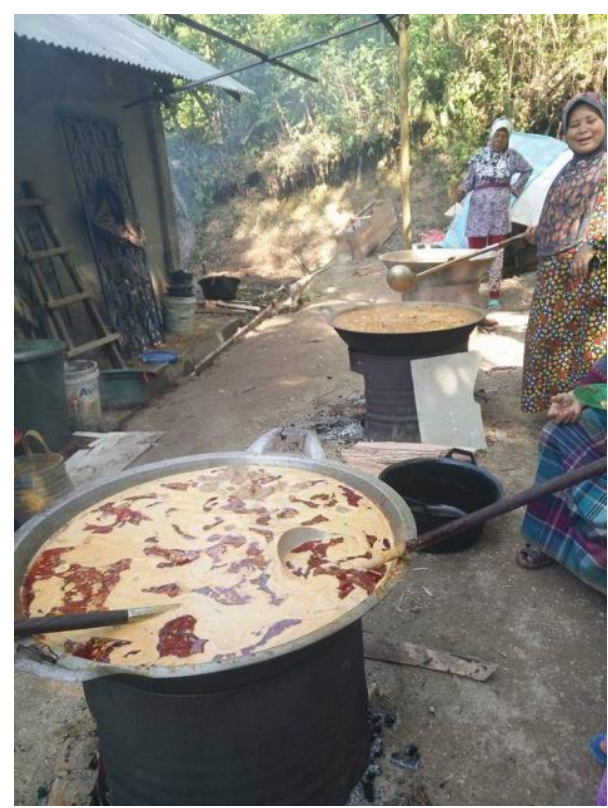

Gambar 2. Acara nganta Petuloh Desa Koto Petai

Dokumentasi Masyarakat Desa Koto Petai

Semakin banyaknya pekerjaan yang yang harus dikerjakan mulai persiapan pelaksanaan, acara pelaksanaan dan pasca pelaksanaan acara seperti membersihkan rumah dan peralatan serta mengembalikan peralatan yang dipinjam ke pemiliknya sehingga muncul istilah "Maka dak tamaka minau dak taminau gawe dak tagawe" (makan dan termakan minum tak terminum kerja tak terkerjakan) oleh karena itu sangat diperlukan kerjasama dalam menyelesaikan semua urusan ketika itu. Petuloh selain di acara pernikahan, terdapat juga di acara tasyakuran dan tahlilan mayit.

3. Pembangunan Rumah

Pada umum rumah di kerinci terdiri dari dua lantai berbahan kayu dan semi permanen, lantai pertama dipungsikan sebagai gudang untuk menyimpan hasil pertanian dan alat-alat pertanian sedangkan lantai dua untuk tempat tinggal. Hasil pengamatan dan analis penulis rumah dua lantai dikerinci dibuat karena tanah di kerinci berbukit-bukit dan sulit mencari tanah yang bermedan datar.

Pembangunan rumah di Kabupaten Kerinci dimulai dari kerangka di mana tiang kayu yang berukuran $15 \mathrm{~cm}$ persegi hingga tata letak kayu-kayu disiapkan. Setelah semuanya tertata dengan baik dan tanpa ada keraguan lagi pada hari yang ditentukan masarakat Desa Koto Petai bergotong royong bersama mendirikan rumah; masyarakat umum bertugas menarik tali bedati yang sudah diikatkan, agar kayu yang sudaah disatukan dapat didirikan 
Pendirian rumah berupa kerangka dilaksanakan secara bersama kurang lebih selama empat jam, biasanya dimulai pada jam 6.30 pagi dimulai dengan doa agar terhindar dari bahaya maklum yang didirikan masih berupa rangka kayu yang mungkin masih bisa terlepas dan juga sangat berat apa lagi kayu yang digunakan kayu pilihan. Setelah do'a dilanjutkan dengan minum kawo (memakan kue-kue yang sudah dibungkus dengan plastik terlebih dahulu daun dan minum air yang dicampur daun kopi mirip teh, sekarang dikenal dengan istilah kopi daun).

Selesai minum kawo pendirian rumah dimulai, bisanya dalam pendirian rumah dimulai dari mendirikan tiang-tiang rumah bagian deret tengah. Di mana tiang-tiang yang sudah dipadukan ditarik bersama sampai berdiri dan diikat di bambu tua yang sudah didirikan lebih awal yang tingginya kurang lebih lima meter agar tidak jatuh dan menimpa masyarakat yang sedang bergotong royong.

Setelah selesai bagian tengah baru didirikan bagian sisi kanan rumah dan kiri, bisanya kedua sisi ini membutuhkan tenaga ekstra dan kehati-hatian karena tiang bagian ini sangat berat karena telah digabungkan dengan konsen. Untuk mendirikan sisi kanan dan kiri bisanya tali bedati diikat ditiang bagian belakang tengah dan depan, masing bagian tali dibuat dua yaitu tali penerik dan tali penahan. Masing-masing terdiri dari dua puluh orang sehingga mendirikan rumah paling tidak dibutuhkan 120 0rang.

Setelah rangka rumah berdiri dan diyakini sudah aman dan tidak jatuh lagi dilanjutkan dengan acara rebutan pisang di mana tandan pisang masak yang sudah digantung dibambu dilempar sedikit-demi sedikit kekerumunan orang sambil berebut pisang sambil tertawa, selanjutnya acara makan bersama biasanya disediakan beberapa rumah di sekitar tuan rumah untuk menampung masyarakat desa makan bersama.

\section{Pembangunan Masjid}

Masjid merupakan tempat ibadah bagi kaum muslimin. Sebagai mana kata Yusuf Qardawi, masjid merupakan lembaga kemanusian pertama. Karena mengharapkan keridhoan Allah, semua orang berlomba-lomba untuk membangun masjid. Bahkan para rajapun berlomba-lomba untuk memegahkan masjid yang mereka bangun. Dalam hal ini, kita akan mengingat jumlah uang yang dikeluarkan oleh Al-Walidi bin Abdil Malik untuk membangun Masjid Bani Umayyah. Karena banyaknya uang yang dikeluarkan untuk membangun masjid dan menggaji para pegawai, hampir tidak ada seorangpun yang bisa memercayai jumlah uang yang dikeluarkan. ${ }^{47}$ Masjid bagi sebuah desa merupakan suatu keharusan, di Desa Koto Petai berdasarkan lokasi pendirian telah empat kali

${ }^{47}$ Yusuf Al-Qaraḍawi, Distorsi Sejarah Islam (Jakarta Timur: Pustaka al-Kauṡar, 2015), 149. 
dibangun masjid semuanya dilaksanakan dengan bekerjasama dan bergotong royong.

Masjid pertama dan kedua dibangung dengan menggunakan material kayu sedangkan masjid ketiga dengan beton (parmanen) ukurannya 16x16 meter terdiri dari lima kubah di tambah satu menera. Masjid ketiga roboh ketika gempa bumi terjadi di Kabupaten Kerinci pada tahun 1995, pada saat itu banyak bangunan dan masjid yang roboh termasuk masjid ini. Masjid di Desa Koto Petai diberi nama Masjid Al-Muhsinin.

Masjid al-Mukhsinin dibangun kembali dengan swadaya masyarakat Desa Koto Petai baik yang berada di desa maupun di perantauan. Sekarang masjid ini berukuran 20x20 meter terdiri dari satu kubah besar berukuran 10x10 meter, berlantai keramik. Masjid ini pernah mendapat juara dua lomba masjid seProvinsi Jambi pada tahun 2012.

5. Pengajian Bulan Suci Ramadan dan Pemotongan Sapi dalam Menyambut Idul Fitri

Umat Islam sangat dianjurkan untuk membaca al-Qur'an, apalagi di bulan suci Ramadan pahalanya berlipatganda, oleh sebab itu masyarakat Desa Koto Petai mentradisikan membaca al-Quran secara bersama dengan membentuk kelompok-kelompok pengajian. Pada awalnya ada tiga kelompok pengajian, yaitu kelompok dahek (klub darat), kelompok tenguh (klub tengah) dan Klub KORBA (kobarkan orde baru). Masing-masing kelompok terdiri dari 20 orang sampai degan 40 orang. Masing-masing anggota kelompok mendapat giliran menjadi tuan rumah pengajian bulan Ramadan. Pengajian ini tidak hanya dihadiri orang tua (ayah) tetapi juga oleh anak-anak dan remaja dari anggota klub. Para remaja yang berumur 12-15 tahun bertugas membawa perlengkapan kelompok dari satu rumah anggota kelompok kerumah yang lain.

Saat sekarang seiring dengan bertambah jumlah penduduk Desa Koto Petai jumlah kelompok pengajian juga bertambah yaitu: kelompok pengajian ahlusunnah wa al-Jamaah, Kelompok pengajian Cinta Makmur dan Ikhwanul muslimin, sehingga kelompok pengajian bulan Ramadan berjumlah enam kelompok.

Tradisi khataman Al-Qur'an pada bulan Ramadan di Koto Petai Kabupaten Kerinci Provinsi Jambi memiliki ke khasan tersendiri. Di mana masyarakat melaksanakan khataman Al-Qur'an secara berkelompok. Berdasarkan wawancara awal dari masyarakat Koto Petai tradisi khataman ini sudah sangat lama dijalankan, menurut K.H Sukani $(80)^{48}$, tidak diketahui secara pasti siapa pelopor tradisi ini, dan kapan dimulainya, karena semasa kecil K.H Sukani sudah 
ada tradisi tersebut. Uniknya juga salah satu kelompok dari beberapa kelompok pengajian yang ada, terdapat nama pengajian Kelompok Korba, nama kelompok ini merupakan singkatan dari kobarkan orde baru. Jika dilihat sejarahnya maka masa orde baru dimulai dari tahun 1965-1998, sebelum kelompok Korba sudah ada kelompok lainnya yang melaksanakan khataman Al-Qur'an di Koto Petai, yakni Kelompok Dabike (Darat), dan Kelompok Tenguh (Tengah). ${ }^{49}$ Perkembangannya hingga sekarang, sudah ada beberapa kelompok pengaiian yaitu, Kelompok Ikbwanul Muslimin, Kelompok Ablusunnah Wal Jama'ah, Nurul Iman.

Waktu pengajian dimulai setelah selesai shalat tarawih sampai dengan sekitar pukul 24.00 WIB setelah itu dilanjutkan dengan doa dan makan bersama yang di persiapkan tuan rumah sesuai dengan kemampuan masing-masing, pengajian ini dimulai dari malam pertama Ramadan sampai dengan malam terakhir. Pengajian kelompok bulan Ramadan sangat bermamfaat sekali bagi warga Desa Koto Petai, karena dengan pengajian kelompok memotivasi orang untuk bisa membaca al-Quran dengan baik, karena bacaannya disimak oleh orang lain, disamping itu kalau ada anggota kelompok, anak atau menantu yang tidak dapat membaca al-Quran akan ketahuan, sehingga memaksa ia untuk belajar membaca al-Quran. Masing-masing kelompok satu hari sebelum lebaran memotong sapi yang dibeli secara bersama-sama untuk menyambut hari raya idul fitri, kecerian terpancar di wajah anggota kelompok, terutama anak-anak ketika pulang membawa daging yang dipotong oleh masing-masing anggota kelompok di pinggir Danau Kerinci, tak jarang orang yang di perantauan ikut bergabung dalam pemotongan sapi ketika pulang dengan kelompok pengajian keluaga mereka.

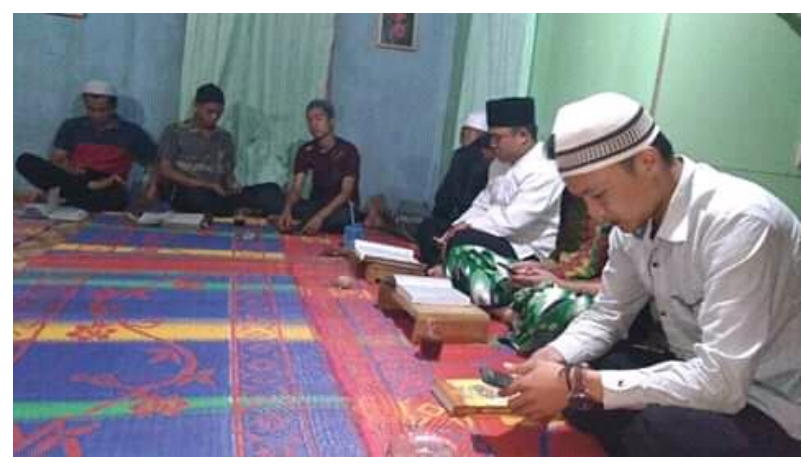

Gambar 3. Pengajian Malam pada bulan Ramadan 2021.

${ }^{49}$ Wawancara Pribadi dengan Pak Habibudin, Masyarakat Desa Koto Petai, 15 Januari 
Sumber: Dokumentasi Masyarakat

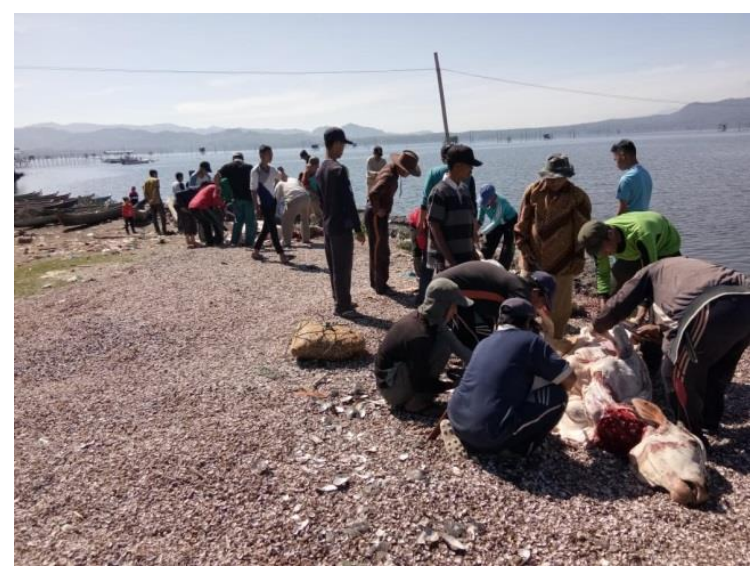

Gambar 4. Acara Pemotongan Sapi Kelompok Pengajian sebelum Idul Fitri

Sumber: Dokumentasi Masyarakat

Bentuk-bentuk kerjasama tersebut menurut hasil wawancara, berangkat dari kebiasaan lalu jadi kebudayaan, kebudayaan selanjutnya menjelma menjadi tradisi yang dulunya, apabila ditinggalkan atau tidak diikuti akan mendapat sanksi. ${ }^{50}$

Kerjasama atau tolong menolong ini telah lama terjadi di masyarakat, selain karena kebutuhan masyarakat sebagai makhluk humanism, kerjasama ini juga merupakan pengamalam dari Al-Qur'an dan hadis, bentuk-bentuk kerjasama ini merupakan aktualisasi dari dan merupakan spirit dari Qs. Al-Maidah: 2 dan juga merujuk kepada hadis-hadis Nabi. Di mana Al-Qur'an memerintahkan untuk tolong menolong dalam kebaikan, serta Nabi mencontohkan bagaimana kerjasama dalam kehidupan sehari-hari, itulah yang diterapkan di masyarakat Koto Petai. ${ }^{51}$ Tradisi kerjasama menimbulkan rasa prihatin, simpati dan merasakan beban yang dipikul oleh orang lain untuk menimbulkan rasa kasih sayang dan tenggang rasa terhadap orang lain, selain sangat besar manfaatnya bagi kehidupan umat manusia, kerjasama merupakan nilai-nilai ajaran Islam. Ada bebeberapa bantuk aktualisasi makna kerjasama di masyarakat Koto Petai, yaitu: dalam bidang pertanian ada istilah Ringko dan Bampok, sebagaimana yang dijelaskan sebelumnya. Pada acara pernikahan, tasyakuran ada yang namanya Patuloh. Selain itu, pembangunan rumah, masjid juga dikerjakan secara bersama-sama. Setiap bulan

${ }^{50}$ Kasim,SE., Selaku Kepala desa Koto Petai, dalam wawancara 20 April 2020, Hariah 01 September 2020 .

51 Wawancara Pribadi dengan Buya Sukani, Tokoh Agama Desa Koto Petai, 9 Desember 2020. 
Ramadan diadakan tilawah bersama untuk menghidupkan bulan Ramadan, serta acara pemotongan sapi pada Setiap lebaran 'Idul Fitri. Kebiasaan ini telah lama ada di masyakaat Desa Koto Petai yang telah membudaya dan menjadi adat Desa Koto Petai. Menurut sumber yang diwawancarai, budaya tersebut merupakan bentuk aktualisasi dari ajaran Islam yang bersumber dari Al-Qur'an dan Hadis.

\section{Kesimpulan}

Bentuk-bentuk kerjasama atau tolong-menolong yang dilakukan oleh masarakat Koto Petai terdiri dari; Ringko dan Bampok, sebagaimana yang dijelaskan sebelumnya. Pada acara pernikahan, tasyakuran ada yang namanya Patuloh. Selain itu, pembangunan rumah, masjid juga dikerjakan secara bersamasama. Setiap bulan Ramadan diadakan tilawah bersama untuk menghidupkan bulan Ramadan, serta acara pemotongan sapi pada Setiap lebaran 'Idul Fitri merupakan aktualisasi ayat al-Qur'an dan hadis, atau diistilahkan ihya' alsunnah (menghidupkan sunnah), juga bisa dikatakan sebagai al-Qur'an yang hidup di masyarakat. Paling tidak, bentuk-bentuk kerjasama ini pertama merupakan pengamalan terhadap sunnah (Al-Qur'an dan hadis), kedua sebagai bentuk kepedulian terhadap sesama dalam masyarakat. Membantu meringankan beban, membentuk rasa persaudaraan. Dalam tradisi kerjasama masarakat Koto Petai, tidak hanya membantu dalam duka tapi juga bekerjasama dalam suka.

\section{Bibliografi}

Abdul Wahid Hasan,dkk. Studi Islam Kontemporer Perspektif Insider/outsider. Yogyakarta: IRCiSoD, 2017

Akram Abdu Kholifah addalimi. Jam'u Al-Qur'an: Dirāsah Tahliliyah Limarwiyyahtihi. Beirut: Dar Al-Kitab Alilmiyyah, 2006.

Assingkily, Muhammad Shaleh, Mahmud Arif, Marhumah Marhumah, and Khamim Zarkasih Putro. "Living Qur'an Dan Hadis Di MI Nurul Ummah (Rutinitas, Ritual Ibadah Dan Pembinaan Akhlak)." ARRIAYAH: Jurnal Pendidikan Dasar 4, no. 1 (June 30, 2020): 27-44. http://journal.iaincurup.ac.id/index.php/JPD/article/view/1402.

Al-Bukhari, Abi Abdullah Muhammad bin Ismail. al-Jami As-Sahih Al-Musnad al-Mukhtasar min Umur Rasulilah SAW wa Sunanihi wa Ayyamihi. Vol. 3. 1,2,3 vol. Kairo: Matba’at As-salafiyyah, 1400.

Al-Buthy, Muhammad Sa’id Ramadan. Sirah Nabawiyah: kajian mendalam manhaj gerakan Islam pada masa Rasulullah (s.a.w.) / Dr.Muhammad Sa’id Ramadan Al-Buthy. Pustaka Dini Sdn. Bhd., 2001. 
Al-Qaraḍawi, Yusuf. Distorsi Sejarah Islam. Jakarta Timur: Pustaka al-Kauṡar, 2015.

Anderson-Levitt, Kathryn. Local meanings, global schooling: Anthropology and world culture theory. Springer, 2003.

An-Nasaaiburi, Imam Abi Husain Muslim bin Al-Khajjaj. Sahih Muslim. Kairo: Daar Al-Hadith, 1991.

Arya Hadi Dharmawan. "Lokakarya Nasional Pengembangan Perkebunan Wilayah Perbatasan Kalimantan.” Pontianak, 2007.

At-Tirmidzi. Sunan At-Tirmidzi. Beirut: Da>r Al-Gharbi al-Islami, 1998.

Deddy Mulyana. Metode Penelitian Kualitatif: Paradigma Baru Ilmu Komunikasi dan Ilmu Sosial Lainnya. Bandung: PT Remaja Rosdakarya, 2006.

Denny, Frederick Mathewson. "Qur'ān Recitation: A Tradition of Oral Performance and Transmission." Oral Tradition, 1989, 5-26. https://mospace.umsystem.edu/xmlui/handle/10355/65410.

Fakultas, Yudi Armansyah, Syariah Uin, Sulthan Thaha, and Saifuddin Jambi. "Kontribusi Seloko Adat Jambi Dalam Penguatan Demokrasi Lokal" 14, no. 1 (2017).

Fisher, Simon, Jawed Ludin, Stave Williams, Dekha Ibrahim Abdi, Richard Smith, dan Sue Williams. "Mengelola konflik: keterampilan dan strategi untuk bertindak." The British Council, Jakarta, Indonesia, 2001.

Greisler, David S, Stupak, Ronald J. Handbook of Technology Management in Public Administration. New York: CRC Taylor and Francis, 2007.

Hasbillah, Ahmad 'Ubaydi. Ilmu Living Quran-Hadis: Ontologi, Epistemologi, Dan Aksiologi. 1st ed. Ciputat: Maktabah Darus-Sunnah, 2019.

Ingrid Mattson. The Story of The Qur'an, Terj. R.Cecep Lukman Yasin. Jakarta: Zaman, 2013.

Ibnu Hisyam. Assiratu An-Nabawiyyatu. Beirut: Dar Al-Kitab Al-Arabi., 1990.

"Inspirasi Alquran Dan Kearifan Lokal Untuk Meningkatkan Profesionalitas Tenaga Kerja | Aziz | AL QUDS : Jurnal Studi Alquran Dan Hadis." Accessed August 20, 2021. http://journal.iaincurup.ac.id/index.php/alquds/article/view/07/pdf.

Irfan, Irfan. "Konsep Al-Mu'awanah Dalam Al-Qur'an (Suatu Kajian Tafsir Tematik)." AL-TADABBUR 6, no. 2 (December 10, 2020): 279-91. http://journal.iain-

ternate.ac.id/index.php/altadabbur/article/view/366. 
IlmuGeografi.com. "7 Faktor yang Mempengaruhi Interaksi Sosial dan Penjelasannya," 8 Juni 2018. https://ilmugeografi.com/ilmusosial/faktor-yang-mempengaruhi-interaksi-sosial.

Kusumasari, Bevaola, dan Quamrul Alam. "Local wisdom-based disaster recovery model in Indonesia." Disaster Prevention and Management: An International Journal 21, no. 3 (1 Januari 2012): 351-69. https://doi.org/10.1108/09653561211234525.

"Living Qur'an di Tanah Kaili (Analisis Interaksi Suku Kaili Terhadap Alquran dalam Tradisi Balia di Kota Palu, Sulawesi Tengah)." Nun : Jurnal Studi Alquran dan Tafsir di Nusantara 3, no. 1 (July 2018): 61-87-87. https://doi.org/10.32459/nun.v3i1.15.

M Al A'zami. The History of The Qur'anic Text; From Revelation to Compilation. Malaysia: IIUM, n.d.

Marcel A Boisard. Humanisme dalam Islam. Jakarta: Bulan Bintang, 1980.

Meliono, Irmayanti. "Understanding the Nusantara Thought and Local Wisdom as an Aspect of the Indonesian Education.” TAWARIKH 2, no. 2 (2011). https://doi.org/10.2121/tawarikh.v2i2.392.

Muhammad Azhim. At-Takhtith lil Al-hijrah Mabadi' Ilmiyah wa Ilhama<t Rabbaniyah. Cairo: Dar At-tawzi' Wa An-nasyr Al-Islamiyah, 2004.

Muhammad Sa’id Ramadan Al-Buthin. Fiqih Al-Sirah. Selangor: Dewan Pustaka fajar, 2008.

Mustafa As-Shiba'i. Al-Sirah Al-Nabawiyah: Durusun Wa' Ibarun. Cairo: $\mathrm{Da}<\mathrm{r}$ Al-salam, 2016.

Nurhasanah, author. "Makna Simbolik Seloko Adat Jambi (Suatu Tinjauan Filosofis).” Universitas Indonesia, 2004. http://lib.ui.ac.id.

Oetzel, John G., dan Stella Ting-Toomey. "Face Concerns in Interpersonal Conflict: A Cross-Cultural Empirical Test of the Face Negotiation Theory." Communication Research, 29 Juni 2016. https://doi.org/10.1177/0093650203257841

Reinhart, A. Kevin. Lived Islam: Colloquial Religion in a Cosmopolitan Tradition. Cambridge: Cambridge University Press, 2020.

Soedigdo, Doddy, Ave Harysakti, dan Tari Budayanti Usop. "Elemen-elemen pendorong kearifan lokal pada arsitektur nusantara." Jurnal Perspektif Arsitektur 9, no. 1 (2014). 
Soerjono Soekanto, dan Budi Suliasto. Sosiologi Suatu Pengantar. Jakarta: Rajawali, 2013.

Syahbah, Muhammad Abu. Madhal Lidira>satil Qur'an. Saudi Arabia: Dar AlLiwa, 1987.

“Tradisi Yasinan (Kajian Living Qur'an Di Ponpes Ngalah Pasuruan) | Mafhum." Accessed August 20, 2021. https://jurnal.yudharta.ac.id/v2/index.php/mafhum/article/view/1612.

Ummatin, Khoiro. "Tiga Model Interaksi Dakwah Rasulullah Terhadap Budaya Lok.” Jurnal Dakwah 15, no. 1 (2014): 179-205. https://doi.org/10.14421/jd.2014.15109.

Voorst, Robert E. Van. Anthology of World Scriptures. Belmont, CA: Thomson Wasworth, 2008.

Young Kimball, dan Reymond W.Mack. Sociology and social life. New York: American Book Company, t.t.

Zuhri, H. "Mendialogkan Alquran Dengan Pembacanya: Studi Atas Living Qur?An Di Periode Klasik Dan Pertengahan.” AL QUDS : Jurnal Studi Alquran Dan Hadis 3, no. 2 (November 25, 2019): 157-84. http://journal.iaincurup.ac.id/index.php/alquds/article/view/030.

Zulfikar, Eko. "Living Quran: Konstruksi Metode Tahfidz Al-Quran Di Majelis Qiraah Wat Tahfidz Pondok Pesantren Murattil Al-Quran Lirboyo Kota Kediri." MAGHZA: Jurnal Ilmu Al-Qur'an Dan Tafsir 4, no. 1 (June 19, 2019): 74-94. https://doi.org/10.24090/MAGHZA.V4I1.2383.

Zulkarnain, Abdul Wahab, and Syaharuddin Syaharuddin. "Peran Ta'awun Dalam Mengentas Kemiskinan Di Kota Makassar." Al-Buhuts 16, no. 2 (December 31, 2020): 1-16. https://doi.org/10.30603/AB.V16I2.1755. 